\title{
Gerakan Sapu Bersih Anemia melalui Food Literacy: Studi pada Pondok Pesantren
}

\author{
Taufik Kurrohman ${ }^{\# 1}$, Farida Wahyu Ningtyias ${ }^{\# 2}$, Tri Candra Setiawati ${ }^{\# 3}$ \\ ${ }^{\# 1}$ Akuntansi, FEB Universitas Jember \\ 1taufik. feb@unej.ac.id

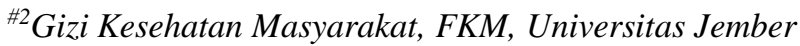 \\ 2farida.fkmeunej.ac.id \\ ${ }^{\# 3}$ Ilmu tanah, Faperta, Universitas Jember \\ ${ }^{3}$ candra.setiawati@gmail.com
}

\begin{abstract}
Pondok Pesantren (PP) mengelola sumber daya yang terbatas, namun harus dioptimalkan terutama dalam hal makanan yang disajikan pada santri. Asupan makanan pada santri yang tinggal di PP akan berpengaruh pada status gizinya. Risiko akan menjadi lebih besar pada santriwati karena terkait fungsi biologisnya, mengalami menstruasi tiap bulan sehingga risiko anemia menjadi lebih besar pada santriwati jika asupan makanan kurang seimbang. Kurang seimbangnya asupan makanan di PP disebabkan rendahnya food literacy para santri dan pengelola PP. Food literacy adalah pengetahuan tentang sumber dan fungsi makanan. Gerakan sapu bersih anemia dilakukan melalui pendidikan gizi dan pelatihan perancangan menu untuk pencegahan anemia yang bisa diterapkan di PP. Kegiatan ini dilaksanakan di PP NI dan PP RRSA Kabupaten Jember. Kegiatan ini berlangsung efektif. Hal ini terbukti dari peningkatan pengetahuan santriwati tentang anemia dan pencegahannya melalui pengaturan asupan makanan serta kemampuan menyusun menu yang sehat dan ekonomis dari para pengelola PP yang semakin baik.
\end{abstract}

Keywords- Anemia, Food Literacy, Gizi, Pondok Pesantren.

\section{Pendahuluan}

Pondok Pesantren (PP) di Jember sebagai lembaga pendidikan alternatif yang hidup di tengah masyarakat pedesaan, walaupun kini menjamur di daerah perkotaan. Pesantren yang tumbuh di pedesaan sebagai tujuan pendidikan alternatif masyarakat pedesaan dengan berlatar belakang ekonomi kelas menengah ke bawah. Bahkan sebagian besar berasal dari latar belakang pendidikan orang tua yang rendah. Namun demikian, Pondok pesantren, khususnya di daerah Jember Jawa Timur memiliki kontribusi yang begitu besar dalam pembangunan sumber daya manusia (Haryono, 2006). Oleh karena itu, dalam proses pembangunan bangsa, terutama yang berhubungan dengan pembangunan sumber daya manusia, kita tidak dapat meninggalkan peran PP yang begitu besar kontribusinya dalam dunia pendidikan.

Pondok Pesantren akan memiliki kontribusi yang lebih besar dalam mencetak Sumber daya manusia (SDM), jika ditopang dengan penyelenggaraan makan dan gizi yang memadai. Penyelenggaraan makan untuk orang banyak tentu memerlukan manajemen yang sesuai dengan ramburambu yang telah diatur dalam manajemen penyelenggaraan makan orang banyak. Sementara yang terjadi di PP penyelenggaraan makan belum sesuai dengan harapan. Sumber gizi tidak harus berasal dari makanan yang bernilai komersial tinggi, tetapi bisa dari pangan lokal yang bisa di dapat di lingkungan sekitar pesantren. Dengan demikian pesantren dapat membangun SDM yang lebih sehat dan berkualitas sebagaimana pepatah 'Di dalam badan yang sehat terdapat jiwa yang sehat'.

Pondok Pesantren NI dan Pondok Pesantren RRSA merupakan pondok pesantren yang berada di Kabupaten Jember dan memiliki banyak santri/santriwati yang berasal tidak hanya dari daerah Jember. Sebagian besar santrinya adalah perempuan. Sebagian besar mereka berada pada usia potensial karena mereka adalah para pelajar yang sedang menuntut ilmu agama dan umum secara bersamaan.

Berdasarkan hasil studi pendahuluan oleh pelaksana didapatkan hasil penyelenggaraan makanan di pondok pesantren belum optimal. Penanggung jawab kegiatan penyelenggaraan makanan di pondok pesantren masih memiliki pengetahuan gizi yang rendah, hal ini terbukti dari belum sesuainya porsi yang disajikan dengan kebutuhan gizi santri yang masih dalam masa pertumbuhan. Jika hal ini tidak diperhatikan dengan baik maka akan berdampak pada status gizi para santri yang juga akan mempengaruhi kualitas sumber daya manusia yang akan dihasilkan.

Beberapa keadaan yang menggambarkan belum optimalnya penyelenggaraan makanan yang ada di PP antara lain: Pertama, belum adanya perencanaan yang baik, hal ini terlihat dari menu masakan yang akan dimasak besok hari 
baru dipikirkan pada saat itu juga. Hal ini terjadi karena belum adanya siklus menu yang diterapkan oleh PP. Kedua, tempat penyimpanan bahan mentah dan makanan yang matang belum terpisah sehingga memperbesar adanya kontaminasi pada makanan yang sudah matang. Ketiga, penyimpanan bahan habis pakai dan bahan kering sudah baik, namun mereka masih belum mengenal sistem FIFO (first in first out) untuk penyimpanan bahan makanan sehingga bahan makanan yang kadaluarsa tidak bisa dikontrol. Keempat, higienitas petugas penyedia makanan juga masih disangsikan karena kebiasaan cuci tangan sebelum memasak masih seringkali diabaikan. Kelima, belum adanya evaluasi terhadap penyelenggaraan makanan yang telah dilaksanakan sehingga tidak pernah diketahui daya terima dan kepuasan santriwati terhadap penyelenggaraan makanan yang telah ada. Pengetahuan manajemen penyelenggaraan makan menjadi solusi masalah ini sehingga ketersediaan sarana bisa dimanfaatkan dengan baik untuk menyediakan makanan yang bergizi untuk santriwati.

Santriwati yang ada di PP biasanya adalah remaja putri dengan rata-rata usia 16-18 tahun. Santriwati ini adalah calon ibu yang akan melahirkan generasi muda harapan bangsa. Dengan demikian mereka harus mempunyai kecukupan gizi yang baik. Masalah gizi yang mengancam remaja putri dengan tingkat konsumsi berkualitas rendah adalah anemia dan kurang energi protein yang akan berkembang menjadi kurang energi kronis saat mereaka menjadi ibu hamil. Anemia dan kurang energi protein menjadi faktor risiko menurunnya kualitas hidup remaja putri. Sebagai seorang pelajar, anemia dan kurang energi protein akan mempengaruhi tingkat konsentrasi dan prestasi di sekolah selain itu sebagai dampak jangka panjang akan mempengaruhi kualitas masa kehamilan mereka sebagai calon ibu di masa mendatang. Anemia dan kurang energi kronis adalah faktor risiko abortus dan berat bayi lahir rendah yang dapat membahayakan ibu dan bayi sekaligus. Hasil pengukuran berat badan dan tinggi badan pada santriwati sebanyak 50 orang, didapatkan hasil $52 \%$ termasuk dalam kategori underweight (IMT<18,5), 40\% termasuk dalam kategori normal (IMT $=18,5-22,99)$ dan $8 \%$ termasuk dalam kategori overweight (IMT=23-27,49) berdasarkan WHO, 2004 klasifikasi untuk orang Asia. Hal ini perlu mendapatkan perhatian karena sebagian besar santriwati memiliki status gizi kurus dan berisiko terhadap penyakit infeksi.

Permasalahan yang dihadapi oleh PP adalah belum optimalnya penyelenggaraan makanan yang dilaksanakan di pondok pesantren. Masalah yang lain adalah status gizi santri dan santriwati yang bermukim di pondok pesantren masih rendah. Kedua masalah ini saling berkaitan karena status gizi merupakan manifestasi konsumsi makanan dan status kesehatan individu.

Dari kedua permasalahan tersebut terdapat peluang untuk melakukan pelatihan dan pendampingan PP untuk dapat melaksanakan penyelenggaraan makanan yang baik, sehat dan bergizi. Ada beberapa alasan mengapa perbaikan penyelenggaraan makanan di PP menjadi prioritas, antara lain: yang pertama penyelenggaraan makanan yang baik akan berimbas pada peningkatan status gizi yang berarti juga memperbaiki kualitas sumber daya manusia. Kedua, pelatihan dan pendampingan penyelenggaraan makanan juga akan meningkatkan pengetahuan gizi dan kesehatan para petugas penyedia makanan dan penanggung jawab penyelenggara makanan, sehingga dalam jangka waktu panjang menjamin ketersediaan makanan sehat di pesantren yang sesuai dengan kebutuhan gizi satri/santriwati.

\section{TARGET DAN LUARAN}

Target dan luaran yang diharapkan dari pelatihan dan pendampingan penyelenggaraan makanan di pondok pesantren adalah:

- Peserta dapat menerapkan pengetahuan tentang manajemen penyelenggaraan makanan meliputi: perencanaan, proses dan evaluasi di skala pondok pesantren.

- Peserta dapat menyusun siklus menu untuk diterapkan dalam penyelenggaraan makanan di pesantren.

- Peserta dapat bertindak sebagai kader untuk menyebarluaskan informasi tentang manajemen penyelenggaraan makanan untuk petugas penyelenggaraan yang ada di pesantren.

- Diharapkan dari kegiatan ini akan didapatkan model penyelenggaraan makanan pesantren yang dapat diduplikasi dan diterapkan oleh pesantren yang lain yang ada di Jember yang dituangkan dalam sebuah modul penyelenggaraan makanan di pesantren.

- Peserta mendapatkan pemahaman tentang anemia dan bahan makanan sumber zat besi tang dapat dimasukkan dalam siklus menu yang dibuat pesantren.

\section{METODE PELAKSANAAN}

Dari permasalahan yang ada di PP tersebut terdapat peluang untuk mengadakan penyuluhan tentang anemia dan pendampingan manajemen penyelenggaraan makanan di pesantren. Pengusul akan melakukan penyuluhan kepada santriwati dan pendampingan kepada petugas penyedia makanan dan penanggung jawab penyelenggaraan makanan yang ada di PP yang akan diwakili oleh 10 orang. Peserta diharapkan keaktifannya dalam mengikuti kegiatan ini sehingga diharapkan nantinya akan menghasilkan model penyelenggaraan makanan di pesantren dan siklus menu 5 atau 7 hari yang bisa diterapkan dan diaplikasikan di pesantren yang ada di Kabupaten Jember. Beberapa fokus materi yang akan disampaikan selama kegiatan pelatihan dan pendampingan akan dibahas dibawah ini :

\section{A. Rancangan siklus menu untuk meningkatkan kualitas konsumsi santriwati berbasis pangan lokal}

Variasi makanan tiap hari sangat dibutuhkan untuk menjamin tercukupinya kebutuhan zat gizi bagi tubuh kita, karena tidak ada makanan tunggal yang mengandung semua 
zat gizi yang dibutuhkan tubuh kita. Nantinya pengurus dan petugas penyelenggara makanan akan diberikan keterampilan dan pengetahuan tentang kandungan zat gizi dan padu padannya sehingga tercipta menu harian yang sesuai dengan kebutuhan gizi santriwati. Pengurus dan petugas penyelengggara makanan akan dibantu untuk menyusun siklus menu 5 hari dan 7 hari yang bisa diaplikasikan dalam penyediaan makanan untuk santriwati.

Petugas penyelenggara makanan juga akan diberikan keterampilan untuk memanfaatkan pangan lokal Jember dalam rangka menyediakan bahan makanan yang berkualitas untuk para santri. Pesantren selalu menyajikan tahu tempe namun pengolahannya sebatas di bumbu kuning atau balado saja. Dengan modifikasi, tahu dan tempe bisa dimanfaatkan untuk pembuatan nugget bersama dengan daun singkong sebagai sumber serat. Nugget home made ini tidak hanya menyediakan protein nabati semata namun juga serat dan sumber vitamin A, beta karoten karena kedelai dikombinasikan dengan daun singkong. Bayam sebagai sumber zat besi bisa dicampurkan dalam nugget.

\section{B. Optimalisasi penyelenggaraan makanan dengan Manajemen penyelenggaraan makanan}

Pengurus dan petugas penyelenggara makanan akan diberikan pengetahuan tentang manajemen penyelenggaraan makanan. Mereka akan dibekali pengetahuan tahapan penyelenggaraan mulai dari persiapan bahan makanan, berupa perencanaan dan pembelanjaan bahan makanan. Tahapan pengolahan bahan makanan berupa persiapan bahan mentah sampai menjadi makanan jadi dan siap santap. Tahap penyajian bahan makanan meliputi penyiapan bahan makanan untuk didistribusikan dan disajikan pada santriwati.

Selain itu juga akan diajarkan cara penyimpangan bahan makanan dengan metode FIFO sehingga keamanan bahan makanan yang disediakan oleh pesantren putri terjamin. Petugas penyelenggara makanan juga akan dibekali dengan perilaku hidup bersih dan sehat karena penyedia bahan makanan juga berkontribusi terhadap keamanan makanan yang disediakan oleh pesantren putri.

\section{Penyediaan makanan sesuai dengan angka kecukupan zat gizi yang dibutuhkan santriwati}

Peningkatan status gizi santriwati menjadi perhatian tim pelaksana karena santriwati yang akan mendapat imbas dari program ini adalah remaja putri yang termasuk dalam kategori usia yang membutuhkan asupan gizi yang mencukupi karena perannya di masa mendatang sebagai calon ibu. Petugas penyelenggara makanan akan diberikan pengetahuan tentang penyediaan bahan makanan sesuai dengan angka kebutuhan gizi. Harapannya makanan yang akan disediakan nantinya jumlahnya sesuai dengan kebutuhan gizi yang dibutuhkan santriwati. Jumlah yang sesuai artinya, kalori, protein, dan lemaknya sesuai dengan angka kecukupan gizi remaja putri.

\section{HASIL DAN PEMBAHASAN}

A. Pelaksanaan Sosialisasi tentang sumber bahan pangan lokal dan anemia

Pelaksanaan sosialisasi dilaksanakan di dua tempat yang berbeda. Pelaksanaan sosialisasi yang pertama dilaksanakan di Aula PP RRSA sunan ampel. Dalam acara tersebut dihadiri oleh 45 santri putra dan putri beserta pengurus dan kiai dari PP RRSA. Acara yang berlangsung selama kurang lebih 6 jam tersebut diawali dengan pre test untuk mengukur tingkat pemahaman para santri beserta para pengurus PP tentang kandungan gizi dari sumber bahan pangan lokal yang tersedia di sekitar PP RRSA dan juga materi tentang Anemia (definisi, gejala-gejala, penyebab, dan cara penanganan atau pencegahannya). Setelah dilakukan pre test lalu diberi pemaparan materi tentang gizi bahan pangan lokal dan anemia. Pemaparan pertama secara umum tentang sumber sumber bahan pangan lokal diberikan oleh Taufik Kurrohman selama kurang lebih 60 menit, dilanjutkan dengan materi kandungan gizi dari sumber bahan lokal oleh Tri Candra Setiawati. Sebelum melanjutkan pada materi ketiga, seluruh peserta dan audiens diberi konsumsi untuk break. Materi ketiga tentang definisi, penyebab, gejala gejala, dan cara pencegahan atau penanganannya diberikan oleh Farida wahyu ningtyias selama kurang lebih 60 menit. Materi ke empat tentang penyusunan siklus menu guna mencegah terjadinya anemia diberikan oleh Farida Wahyu Ningtyias selama kurang lebih 60 menit. Adapun pemaparan materi menggunakan media pembelajaran berupa alat peraga dan power point yang interaktif membuat seluruh audiens memahami materi yang diberikan. Selesai pemaparan materi oleh tim, dilanjutkan tanya jawab dan diskusi dengan seluruh audiens selama kurang lebih 120 menit. Acara terakhir dilanjutkan dengan post test tentang sumber bahan pangan lokal dan anemia. Pre test dan post test ini diberikan untuk mengukur tingkat pemahaman dari audiens. Adapun materi serta hasil pre dan post test terlampir.

Acara sosialisasi yang kedua dilaksanakan di PP NI. Dalam acara tersebut dihadiri oleh 350 santri putri beserta pengurus PP. Acara yang berlangsung selama kurang lebih 6 jam tersebut diawali dengan pre test untuk mengukur tingkat pemahaman para santri beserta para pengurus PP tentang kandungan gizi dari sumber bahan pangan lokal yang tersedia di sekitar PP NI dan juga materi tentang Anemia (definisi, gejala-gejala, penyebab, dan cara penanganan atau pencegahannya). Setelah dilakukan pre test lalu diberi pemaparan materi tentang gizi bahan pangan lokal dan anemia. Pemaparan pertama secara umum tentang sumber sumber bahan pangan lokal diberikan oleh Taufik Kurrohman selama kurang lebih 60 menit, dilanjutkan dengan materi kandungan gizi dari sumber bahan lokal oleh Tri Candra Setiawati. Sebelum melanjutkan pada materi ketiga, seluruh peserta dan audiens diberi konsumsi untuk break. Materi ketiga tentang definisi, penyebab, gejala gejala, dan cara pencegahan atau penanganannya diberikan oleh Farida Wahyu Ningtyias selama kurang lebih 60 menit. 
Materi ke empat tentang penyusunan siklus menu guna mencegah terjadinya anemia diberikan oleh Farida Wahyu Ningtyias selama kurang lebih 60 menit.

Adapun pemaparan materi menggunakan media pembelajaran berupa alat peraga dan power point yang interaktif membuat seluruh audiens memahami materi yang diberikan. Selesai pemaparan materi oleh tim, dilanjutkan tanya jawab dan diskusi dengan seluruh audiens selama kurang lebih 120 menit. Acara terakhir dilanjutkan dengan post test tentang sumber bahan pangan lokal dan anemia. Pre test dan post test ini diberikan untuk mengukur tingkat pemahaman dari audiens. Adapun tingkat pemahaman sebelum diberikan pelatihan adalah sebagai berikut:

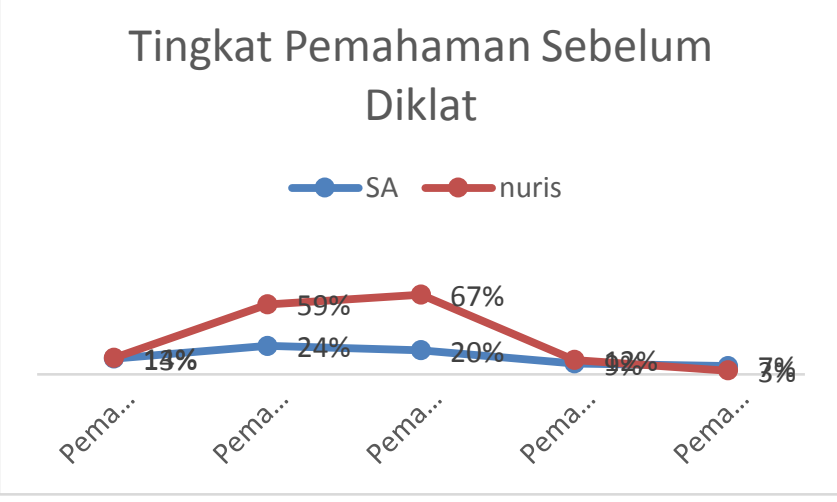

Gambar 1. Grafik tingkat pemahaman sebelum diklat

Dalam grafik diatas tingkat pemahaman terhadap anemia cukup rendah, baik itu di PP RRSA maupun di PP NI. Hal ini akan berdampak pada potensi penyakit anemia yang akan dialami oleh para santri. Namun setelah diberikan pendidikan dan pelatihan sesuai dengan program dan metode yang diterapkan hasilnya sangat bagus. Terlihat di rata rata diatas $85 \%$ dari masing2 PP tersebut. Grafik untuk tingkat pemahaman setelah diberi diklat dapat dilihat berikut ini:

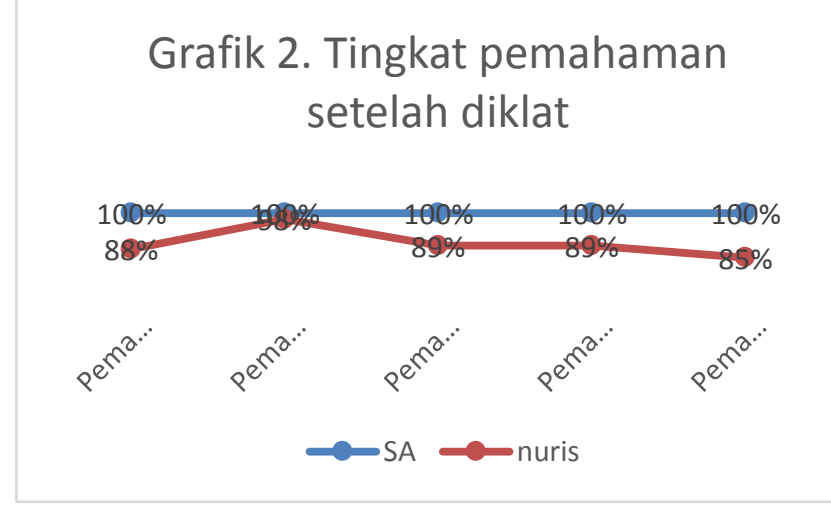

Gambar 2. Grafik tingkat pemahaman setelah diklat

\section{B. Penyusunan Siklus menu harian bebas anemia}

Tahapan berikutnya setelah pemaparan materi tentang produk bahan pangan lokal dan anemia adalah penyusunan siklus menu harian di lingkungan PP RRSA. Dalam penyusunan menu tersebut dilakukan melalui mekanisme focus group discussion (FGD) bersama dengan pengelola pesantren dan perwakilan santri. Menu dirancang dengan memanfaatkan bahan pangan lokal yang mudah ditemui disekitar PP. Hal ini juga bertujuan agar penyelenggaraan makanan di PP RRSA berlangsung efektif, efisien, dan ekonomi. Adapun hasil dari FGD tersebut untuk penyusunan menu adalah sebagai berikut:

TABEL 1. CONTOH DAFTAR MENU YANG DAPAT DIBUAT DI PP RRSA

\begin{tabular}{|l|l|l|}
\hline Menu Makan Pagi & Menu Makan Siang & Menu Makan Malam \\
\hline $\begin{array}{l}\text { Nasi, Telur Opor, Tempe Mendoan, } \\
\text { Tumis Sayur, }\end{array}$ & $\begin{array}{l}\text { Nasi, Pepes } \\
\text { Ikan, Tahu Bumbu } \\
\text { Petis,Urap sayur, } \\
\text { Jeruk }\end{array}$ & $\begin{array}{l}\text { Nasi, Ayam Pelalah } \\
\text {, Perkedel } \\
\text { Kentang, Sayur Lodeh }\end{array}$ \\
\hline $\begin{array}{l}\text { Nasi } \\
\text { Telur bb. semur, Tahu bb. bali, Cah } \\
\text { Sayur }\end{array}$ & $\begin{array}{l}\text { Nasi, sayur bening } \\
\text { bayam, telur bumbu } \\
\text { merah, tempe goreng, } \\
\text { jeruk nipis }\end{array}$ & $\begin{array}{l}\text { Nasi, Tumis tempe } \\
\text { kecap, Ikan bb. } \\
\text { balado, Oseng } \\
\text { kangkung Sambal } \\
\text { terasi }\end{array}$ \\
\hline $\begin{array}{l}\text { Nasi, Omelete telur, Tempe goreng, } \\
\text { Pecel }\end{array}$ & $\begin{array}{l}\text { Nasi, Ikan Bumbu } \\
\text { Balado, Tahu Bumbu } \\
\text { Bali,Sayur Asem- } \\
\text { Asem Buncis }\end{array}$ & $\begin{array}{l}\text { Nasi, Ayam Rica- } \\
\text { Rica, Sambal Goreng } \\
\text { Tempe,Sayur Lodeh } \\
\text { nangka muda }\end{array}$ \\
\hline $\begin{array}{l}\text { Nasi, Gulai } \\
\text { Telur, Tempe bb Tomat, Sayur } \\
\text { Bening }\end{array}$ & $\begin{array}{l}\text { Nasi, Ikan bb. pedas, } \\
\text { Pepes jamur, Sayur } \\
\text { Asem, jeruk }\end{array}$ & $\begin{array}{l}\text { Nasi, Telur ceplok, } \\
\text { Semur Tahu, Cah } \\
\text { Kangkung }\end{array}$ \\
\hline
\end{tabular}

Sedangkan penyusunan menu di PP NI juga berlangsung melalui FGD. Dalam penyusunan menu tersebut dilakukan melalui mekanisme focus group discussion bersama dengan pengelola pesantren dan perwakilan santri. Menu dirancang dengan memanfaatkan bahan pangan lokal yang mudah ditemui disekitar PP. Hal ini juga bertujuan agar penyelenggaraan makanan di PP NI berlangsung efektif, efisien, dan ekonomi. Adapun hasil dari FGD tersebut untuk penyusunan menu adalah sebagai berikut:

TABEL 1. CONTOH DAFTAR MENU YANG DAPAT DIBUAT DI PP NI

\begin{tabular}{|l|l|l|}
\hline Makan Pagi & Makan Siang & Makan Malam \\
\hline $\begin{array}{l}\text { Nasi, Telur bb. balado } \\
\text { Kroket tahu, Sayur } \\
\text { asemkecambah }\end{array}$ & $\begin{array}{l}\text { Nasi, Botok Teri, Kroket } \\
\text { Tempe, Sayur Bening } \\
\text { bayam }\end{array}$ & $\begin{array}{l}\text { Nasi, Perkedel kentang } \\
\text { sawi, Tempe bb. terik } \\
\text {, Sayur Lodeh labu siam }\end{array}$ \\
\hline $\begin{array}{l}\text { Nasi, Gulai Telur, Sambel } \\
\text { Goreng Tempe, Sayur } \\
\text { Bening Bayam }\end{array}$ & $\begin{array}{l}\text { Nasi, Telur bb. Rendang } \\
\text {, Tempe bb kecap, Tumis }\end{array}$ & $\begin{array}{l}\text { Nasi, Daging bb. semur } \\
\text {, Tahu bb. pedas, Gulai } \\
\text { Daun Singkong }\end{array}$ \\
\hline $\begin{array}{l}\text { Nasi, Telur bb.Kuning } \\
\text { Tempe bb. Pedas, Sayur } \\
\text { Bening Kacang Panjang }\end{array}$ & $\begin{array}{l}\text { Nasi, Ikan Serapah, Tahu } \\
\text { Bumbu Petis, Sayur }\end{array}$ & $\begin{array}{l}\text { Nasi, Ikan bb Tomat, } \\
\text { Kamur Krispi, Lodeh }\end{array}$ \\
\hline
\end{tabular}

Kedua alternatif menu tersebut dapat saling menggantikan satu sama lain tergantung pada ketersediaan bahan dan dana di PP. Selain itu kedua alternatif menu tersebut bisa diadopsi oleh PP lain dengan menyesuaikan sumber bahan pangan lokal yang tersedia di sekitar

\section{KESIMPULAN}

Berdasarkan pada hasil dari pelatihan dan sosialisasi tentang penyusunan siklus menu serta identifikasi sumber pangan lokal dan anemia, maka diperoleh kesimpulan sebagai berikut: 
- Peserta dapat menerapkan pengetahuan tentang manajemen penyelenggaraan makanan meliputi: perencanaan, proses dan evaluasi di skala pondok pesantren.

- Peserta dapat menyusun siklus menu untuk diterapkan dalam penyelenggaraan makanan di pesantren.

- Peserta dapat bertindak sebagai kader untuk menyebarluaskan informasi tentang manajemen penyelenggaraan makanan untuk petugas penyelenggaraan yang ada di pesantren.

- Peserta mampu menyusun model penyelenggaraan makanan pesantren yang dapat mencegah terjadinya anemia serta dapat diduplikasi dan diterapkan oleh pesantren yang lain yang ada di Jember yang dituangkan dalam sebuah modul penyelenggaraan makanan di pesantren.

- Peserta mendapatkan pemahaman tentang anemia dan bahan makanan sumber zat besi tang dapat dimasukkan dalam siklus menu yang dibuat pesantren

\section{UCAPAN TERIMA KASIH}

Terima kasih kami sampaikan kepada pihak Universitas Jember melalui skema dana BOPTN tahun 2017 kami dapat melaksanakan kegiatan ini. Terimakasih juga kami sampaikan kepada pihak PP RRSA dan PP NI Jember yang telah bersedia dan bekerjasama dalam rangka pengentasan buta anemia di lingkungan pondok pesantren. Dan juga kepada mahasiswa Gizi Angkatan 2014 yang membantu.

\section{DAFTAR PUSTAKA}

[1] Haryono, A. 2006. Perilaku Kewirausahaan Lulusan Pesantren Salaf (Sebagai Upaya Mendesain Kurikulum Pesantren Salaf Berbasis Budaya dan Berorientasi Kewirausahaan). Laporan Penelitian. Lembaga Penelitian. Universitas Jember.

[2] Giovannini M et al. 2008. Breakfast: a good habit, not a repetitive custom. The Journal of Inter $\neg$ national Medical Research, 36, 613624.

[3] Muchtar M, Julia, M \& Indria LG. 2011. Sarapan dan jajan berhubungan dengan kemampuan konsentrasi pada remaja. Jurnal Gizi Klinik, 8(1), 28-35.

[4] Rampersaud GC, Pereira MA, Girard BL, Adams J, \& Metzl JD. 2005. Breakfast habits, nutritional status, body weight, and academic perfor $\neg$ mance in children and adolescents. Journal of the American Dietetic Association, 105(5), 743-760.

[5] Anonim. 2000. Selayang pandang Pondok Pesantren Nurul Islam (NI) Jember. http://puanamalhayati.or.id/archives/1051

[6] Depkes RI. 2003. Indikator Indonesia Sehat 2010. Jakarta: Depkes RI

[7] Depkes RI. 2007. Pedoman Pelayanan Gizi Rumah Sakit Edisi Revisi. Jakarta: Departemen Kesehatan RI Direktorat Jenderal Bina Kesehatan Masyarakat.

[8] Kemenkes RI. 2013. Peraturan menteri kesehatan RI no 75 tahun 2013 tentang angka kecukupan gizi yang dianjurkan bagi bangsa Indonesia. Jakarta: Kementerian Kesehatan RI.

[9] Badan Ketahanan Pangan. 2011. Daftar Penukar Bahan Makanan. Jakarta

[10] Mukrie, N.A.,et al.1990. Manajemen Pelayanan Gizi Institusi. Depkes RI Jakarta.

[11] Purwaningtiyas, S. 2013. "Gambaran Penyelenggaraan Makan Di Pondok Pesantren Al-Qodiri Kabupaten Jember". Tidak
Dipublikasikan. Skripsi. Jember. Fakultas Kesehatan Masyarakat Universitas Jember.

[12] Moehyi S. Penyelenggaraan Makanan Institusi dan Jasa Boga. Jakarta: Bhratara; 1992.

[13] www. anekaresepmasakan.info

[14] Badan Ketahanan Pangan, 2011. Daftar Bahan Makanan Penukar URT

[15] Peraturan Menteri Kesehatan Republik Indonesia Nomor 1096/Menkes/Per/VI/2011 Tentang Sanitasi Jasaboga

[16] WHO. 2015. Food Borne Disease. www.who.int.foodbornedisease.

[17] Pujiasih, E. 2012. Blogspot.Com. Kumpulan Pengetahuan Ilmu Kesehatan Masyarakat 